\title{
Correction to: Regulation of GAD65 expression by SMAR1 and p53 upon Streptozotocin treatment
}

Sandeep Singh ${ }^{2 *}$, Varsheish Raina ${ }^{1}$, Pavithra Lakshminarsimhan Chavali ${ }^{1}$, Taronish Dubash ${ }^{1}$, Sreenath Kadreppa ${ }^{1}$, Pradeep Parab ${ }^{1}$ and Samit Chattopadhyay ${ }^{1 *}$

\section{Correction to: BMC Molecular Biol 13, 28 (2012)}

https://doi.org/10.1186/1471-2199-13-28

Following publication of the original article [1], the authors reported that in Fig. 3C, the western blot data for GAD65 and p53 are the same.
Below is the correct Fig. 3C.

C

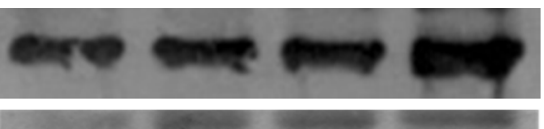

GAD65

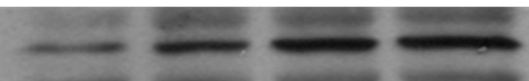

pSer15 p53

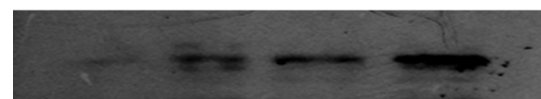

p53

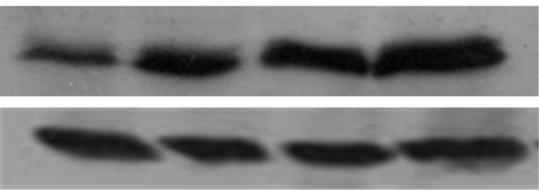

SMAR1

Ctrl

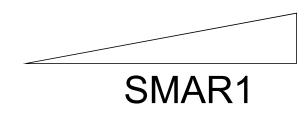

Actin

Fig. 3 SMAR1 upregulates GAD65 expression. C. SMAR1 was over-expressed in Rin5f cells and samples were processed for western blot analysis 48 hrs post transfection. Figure shows western blot analysis of these samples using GAD65, phospho serine 15 p53 and SMAR1 expression while actin was used as loading control

Published online: 17 August 2020

\section{Reference}

1. Singh S, Raina V, Chavali PL, et al. Regulation of GAD65 expression by SMAR1 and p53 upon Streptozotocin treatment. BMC Molecular Biol. 2012; 13:28 https://doi.org/10.1186/1471-2199-13-28.

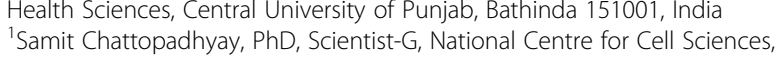
Pune 411007, India

(c) The Author(s). 2020 Open Access This article is licensed under a Creative Commons Attribution 4.0 International License, which permits use, sharing, adaptation, distribution and reproduction in any medium or format, as long as you give appropriate credit to the original author(s) and the source, provide a link to the Creative Commons licence, and indicate if changes were made. The images or other third party material in this article are included in the article's Creative Commons licence, unless indicated otherwise in a credit line to the material. If material is not included in the article's Creative Commons licence and your intended use is not permitted by statutory regulation or exceeds the permitted use, you will need to obtain permission directly from the copyright holder. To view a copy of this licence, visit http://creativecommons.org/licenses/by/4.0/ The Creative Commons Public Domain Dedication waiver (http://creativecommons.org/publicdomain/zero/1.0/) applies to the data made available in this article, unless otherwise stated in a credit line to the data. 